\title{
SKIRTINGO AMŽIAUS IR MEISTRIŠKUMO LIETUVOS JAUNŲJŲ DVIRATININKŲ AEROBINIS PAJĖGUMAS
}

\author{
Gintautas Volungevičius, Arvydas Stasiulis, Pranas Mockus
} Lietuvos kūno kultūros akademija, Kaunas, Lietuva

\begin{abstract}
Gintautas Volungevičius. Biomedicinos mokslų magistras. Lietuvos kūno kultūros akademijos Taikomosios fiziologijos ir kineziterapijos katedros biomedicinos mokslų doktorantas. Mokslinių tyrimų kryptis — jaunujų dviratininkų aerobinio pajejgumo tyrimas.
\end{abstract}

\section{SANTRAUKA}

Iš nuosekliai didinamo krūvio metu pastebimu kvèpavimo ir duju apykaitos, laktato kaupimosi slenksčio (LKS), didžiausios darbo galios $\left(N_{\max }\right)$, maksimaliojo deguonies suvartojimo $\left(V O_{2 m a x}\right)$, darbo veiksmingumo, maksimalios La koncentracijos dirbant pastoviosios bükles salygomis, I tipo raumenu skaidulu procento vastus lateralis raumenyje rodikliu galima prognozuoti dviratininku varžybu rezultatus (Mujika, Padilla, 2001).

Elito plento dviratininkai yra skirtingu antropometriniu duomenu (Swain et al., 1987), tačiau visu ju aerobiniai rodikliai aukšti: maksimalusis darbo galingumas siekia 370-570 W, VO $\mathrm{2max}_{-}$nuo 4,4 iki 6,4 l / min, o galingumas pasiekus LKS - nuo 300 iki 500 W (Padilla et al., 1999; Lucia et al., 2000). Literatūroje šykštu duomenu apie jaunesnio amžiaus dviratininku aerobinio pajëgumo rodiklius ir ju kaita per treniruotes.

Tyrimo tikslas - palyginti jaunučiu ir jaunimo grupiu dviratininku aerobinio pajègumo rodiklius atliekant nuosekliai didinama krūvị veloergometru, kai pedalai sukami plento lenktynèms büdingu 90 aps. / min (Lucia et al., 2001) dažniu. Buvo tiriami aštuoni 15-16 m. jaunučiu grupès (treniravimosi stažas 2-3 m.) ir aštuoni 19-23 m. jaunimo grupés (treniravimosi stažas 5-8 m.) dviratininkai. Norint nustatyti aerobini pajëguma, tiriamasis po pramankštos veloergometru „Ergoline“ atliko nenutrūkstama kas 5 s nuosekliai po 2 W didinama krūvį. Viso tyrimo ir atsigavimo metu naudojant nešiojama íranga ,, Oxycon Mobile“ (Jaeger, Vokietija) buvo registruojami duju apykaitos rodikliai ir širdies susitraukimu dažnis, vèliau pagal ju kaita priklausomai nuo krūvio nustatomi aerobinio pajègumo rodikliai. Jaunimo grupès dviratininku absoliučios $V O_{2 \max }$, ventiliaciniu slenksčiu, didžiausios darbo galios, submaksimalios plaučiu ventiliacijos rodikliai buvo reikšmingai didesni negu jaunučiu grupejje. Santykiniai aerobinio pajėgumo rodikliai ( $\mathrm{VO}_{2 \max }$, ventiliaciniai slenksčiai vienam kūno masès $\mathrm{kg}$ ), submaksimalios ir maksimalios ŠSD reikšmės, darbo veloergometru veiksmingumas buvo panašūs skirtingose amžiaus grupése. Tyrimo rezultatai rodo, kad atliekant nuosekliai didinama fizini krūvi veloergometru vyresniu ir didesnio meistriškumo jaunuju dviratininku geresni tik absoliučius aerobinès galios rodikliai.

Raktažodžiai: maksimalusis deguonies suvartojimas, ventiliaciniai slenksčiai, aerobinis pajëgumas, jaunuju dviratininku amžius.

\section{IVADAS}

I š nuosekliai didinamo krūvio metu pastebimų kvėpavimo ir dujų apykaitos, laktato kaupimosi slenksčio (LKS), didžiausios darbo galios $\left(\mathrm{N}_{\max }\right)$, maksimaliojo deguonies suvartojimo $\left(\mathrm{VO}_{2 \max }\right)$, darbo veiksmingumo, maksimalios La koncentracijos dirbant pastoviosios būklès sąlygomis, taip pat I tipo raumenų skaidulų procento vastus lateralis raumenyje rodikliu galima prognozuoti dviratininkų varžybų rezultatus $(\mathrm{Mu}-$ jika, Padilla, 2001). Elito plento dviratininkai yra skirtingų antropometrinių duomenų (Swain et al., 1987), tačiau visu jų aerobiniai rodikliai aukšti: maksimalusis galingumas siekia $370-570 \mathrm{~W}$, $\mathrm{VO}_{2 \max }$ - nuo 4,4 iki 6,41/ min, o galingumas pasiekus LKS - 300 iki $500 \mathrm{~W}$ (Padilla et al., 1999; Lucia et al., 2000). A. Lucia ir kt. (2001 a) 
Giro d'Italia, Tour de France ir Vuelta a Espana didžiujų daugiadienių lenktynių metu pastebejo, kad profesionalai galèjo išlaikyti darbo intensyvumą, artimą antram ventiliaciniam slenksčiui (VeS2) arba deguonies suvartojimą, lygų 90\% nuo $\mathrm{VO}_{2 \max }$, apie 60 min. Aukštas VeS2 yra svarbus dviratininkui, lenktyniaujančiam kalnuose, nes tenai 30-60 min reikia dirbti VeS2 arba LKS artimu intensyvumu (Lucia et al., 1998). Ko gero, dèl to labiausiai skiriasi geriausių mėgèjų ir elito dviratininkų submaksimalūs aerobinio pajègumo rodikliai, ypač prie $\mathrm{VeS} 2$, nors $\mathrm{VO}_{2 \max }$ yra panašūs (Lucia et al., 1998). Vieną profesionalų komandą paprastai sudaro skirtingos specializacijos dviratininkai, kurie sąlygiškai skirstomi į lygumu, kalnų, laiko lenktynių specialistus, finišo meistrus ir universalus (Mujika, Padilla, 2001). Tai lemia dviratininkų antropometrinių, fiziologinių ir kūno masės rodiklių santykis. Pažymètina, kad atskirose lenktynėse gerai lenktyniaujantys dviratininkai geba puikiai važiuoti lygumų ir kalnų trasose, taip pat individualiose bendrojo starto bei komandinèse lenktynèse (Mujika, Padilla, 2001). Per asmenines laiko lenktynes (ALL) darbo galingumas, artimas LKS, siekia 400-420 W (trumpesnèse ALL), o ilgesnèse jis artimas individualiam laktatiniam slenksčiui (LS) ir siekia 370-390 W. Pulso dažnis (PD) būna aukštas, bet pastovus. Grupinèse lenktynèse elito dviratininkai ịveikia $200 \mathrm{~km}$ ir daugiau, todèl darbo intensyvumas būna dar mažesnis: lygumoje vidutiniškai jis siekia $210 \mathrm{~W}$, kalnuose - $270 \mathrm{~W}$ (Lucia et al., 2000).

Tyrimų su jaunesnio amžiaus dviratininkais pasaulyje (Tsunawake et al., 1993) ir Lietuvoje atlikta nedaug. Šykštu duomenų apie jaunuju dviratininkų aerobinio pajègumo rodiklius sukant pedalus skirtingu dažniu. Jeigu elito dviratininkai dažnesni pedalų sukimą gali kompensuoti didesne galia (pasirinkdami didesnę pavarą), tai 13-14 m. (vaikų), 15-16 m. (jaunučiu), 17-18 m. (jaunių) dviratininkų varžybose didžiausios pavaros yra draudžiamos. Todèl rezultatus šiose amžiaus grupèse dažniausiai lemia geresnis aerobinis pajègumas, esant didesniam pedalų sukimo dažniui. Jaunimo (19-23 m.) grupès ir elito dviratininkai gali važiuoti bet kuria pavara. Varžybinès veiklos tyrimai (Lucia et al., 2001 b) rodo, kad plento lenktynèse sportininkai vidutiniškai pedalus suka 90 aps. / min, treko lenktynèse - 110 aps. / min ir tik įveikdami kalnuotus plento lenktynių nuotolius pasirenka pedalų sukimo dažni, artimą 70 aps. / min. Mūsų tyrimas leistų išaiškinti kiekvieno dviratininko rezultatą ribojančius aerobinio pajègumo rodiklius, išskirti rungti, kuriai sportininkas labiausiai tinka. Tai padètu tiksliau vykdyti gabių sportininkų atranką, orientuoti dviratininkus pasirenkant sportinę specializaciją, prognozuoti konkrečiu sportininkų rengimo kryptis siekiant geriausių sportinių rezultatų.

Tyrimo tikslas - palyginti jaunučių ir jaunimo grupių dviratininku aerobinio pajègumo rodiklius atliekant nuosekliai didinamą krūvị veloergometru, kai pedalai sukami plento lenktynèms būdingu 90 aps. / min dažniu.

\section{TYRIMO METODIKA}

Tiriamieji. Buvo tiriami aštuoni $15-16 \mathrm{~m}$. jaunučiu grupès (treniravimosi stažas $2-3 \mathrm{~m}$.) dviratininkai (amžius - 15,5 $\pm 0,5 \mathrm{~m}$., ūgis $175 \pm 6,2 \mathrm{~cm}$, kūno mase $-63,6 \pm 10,7 \mathrm{~kg})$ ir aštuoni $19-23 \mathrm{~m}$. jaunimo grupès (treniravimosi stažas $5-8 \mathrm{~m}$.) dviratininkai (amžius $19,0 \pm 1,1 \mathrm{~m} ., \bar{u} g i \mathrm{~s}-184,9 \pm 4,2 \mathrm{~cm}$, kūno masè $-75,3 \pm 3,6 \mathrm{~kg}$ ).

Nuosekliai didinamo krūvio testas (NDK). Norint nustatyti aerobini pajègumą, tiriamasis po pramankštos veloergometru „Ergoline“ atliko nenutrūkstamą kas $5 \mathrm{~s}$ nuosekliai po $2 \mathrm{~W}$ didinamą krūvį. Krūvis buvo atliekamas sukant pedalus $90 \pm 2$ aps. / min dažniu. Pradinis $20 \mathrm{~W}$ krūvis buvo didinamas tol, kol dviratininkas nebegebejo išlaikyti reikiamo dažnio ar dèl nuovargio atsisakydavo tęsti testą. Tada tiriamasis 5 min ilsejjosi gulèdamas.

Kraujo laktato koncentracijos nustatymas. Kapiliarinio kraujo méginiai buvo imami iš piršto praejus 5 ir 20 min po NDK. Laktato koncentracija buvo nustatoma naudojant "Accutrend Lactate“ (Vokietija) analizatorių.

Dujų apykaitos registravimas ir analizè. Viso tyrimo ir atsigavimo metu naudojant nešiojamą iranga „Oxycon Mobile“ (Jaeger, Vokietija) buvo registruojami dujų apykaitos rodikliai: deguonies suvartojimas $\left(\mathrm{VO}_{2}\right)$, anglies dioksido išskyrimo greitis $\left(\mathrm{VCO}_{2}\right)$, kvèpavimo dažnis, kvèpavimo tūris ir plaučiu ventiliacija (Ve). Iš jų vẻliau buvo apskaičiuojami išvestiniai rodikliai, reikalingi ventiliaciniams slenksčiams nustatyti: ventiliaciniai $\mathrm{O}_{2}$ ir $\mathrm{CO}_{2}$ ekvivalentai, kvejpavimo koeficientas. Pirmu ventiliaciniu slenksčiu (VeS1) buvo laikomas darbo intensyvumas, virš kurio atliekant NDK pradeddavo didèti ventiliacinis $\mathrm{O}_{2}$ ekvivalentas, o VeS2 - darbo intensyvumas, virš kurio atliekant NDK pradèdavo didèti ventiliacinis $\mathrm{CO}_{2}$ ekvivalentas, taip pat dar labiau pagreitedavo ventiliacinio $\mathrm{O}_{2}$ ekvivalento 
prieaugis. $\mathrm{VO}_{2 \max }$ buvo laikomas didžiausias NDK metu per $15 \mathrm{~s}$ pasiektas $\mathrm{VO}_{2}$. Santykinis $\mathrm{VO}_{2 \max }$ buvo apskaičiuojamas absoliutų rodikli 1 / min padalijus iš tiriamojo kūno masès. Taip pat buvo analizuojami absoliutūs ir santykiniai (\% nuo didžiausių) Ve, $\mathrm{VO}_{2}$ ir ŠSD rodikliai. Pastarasis rodiklis buvo registruojamas naudojant pulso matuokli su atmintimi Polar S810 (Suomija).

Tyrimo organizavimas. Tyrimai atlikti LKKA Sporto fiziologijos laboratorijoje. Kiekvienas tiriamasis prieš NDK testą atlikdavo pramankštą (10 min krūvị $50 \mathrm{~W}$ galingumu). Paskui uždèjus ŠSD ir dujų apykaitos registravimo įrangą buvo atliekamas NDK, po kurio tiriamasis guledavo 5 min. Praejus 5 ir 20 min po NDK, buvo imamas kapiliarinis kraujas iš piršto laktato koncentracijai nustatyti.

Matematinė statistika. Buvo apskaičiuojami duomenu aritmetiniai vidurkiai ir standartiniai nuokrypiai. Tiriamujų grupių duomenys buvo palyginami taikant neparametrinius metodus. Statistiniu hipoteziu patikimumui nustatyti pasirinktas $p<0,05$ lygmuo. Apskaičiavimai atlikti naudojantis kompiuterinemis programomis „Microsoft Excel“ ir „Statistika for Windows“.

\section{REZULTATAI}

Tyrimo rezultatai pateikti lentelèje.

Jaunimo grupès dviratininkų ventiliacinių slenksčių ir didžiausios testo metu pasiektos galios absoliučios reikšmės buvo statistiškai reikšmingai didesnès negu jaunučiu (1 pav.).

Santykinès šių rodiklių reikšmès tarp grupių nesiskyrè (2 pav.).

Maksimalios ir submaksimalios ŠSD reikšmès taip pat buvo panašios abiejose dviratininkų amžiaus grupèse (3 pav.).

\begin{tabular}{|c|c|c|c|c|}
\hline \multirow{2}{*}{ Rodikliai $\quad$ Tiriamieji } & \multicolumn{2}{|c|}{ Jaunimas } & \multicolumn{2}{|c|}{ Jaunučiai } \\
\hline & Vidurkis & St. nuokr. & Vidurkis & St. nuokr. \\
\hline Amžius, m. & 19,14 & 1,17 & 15,75 & 1,04 \\
\hline Ūgis, cm & 184,43 & 3,83 & 175,75 & 6,09 \\
\hline Svoris, kg & 75,29 & 5,13 & 63,75 & 10,99 \\
\hline 1 ventiliacinis slenkstis, $\mathrm{W}$ & 243,43 & 36,44 & 180,75 & 55,32 \\
\hline 2 ventiliacinis slenkstis, $\mathrm{W} / \mathrm{kg}$ & 3,22 & 0,35 & 2,84 & 0,87 \\
\hline Ventiliacija (VeS1), 1 / min & 66,29 & 10,50 & 56,21 & 15,21 \\
\hline ŠSD (VeS1), tv. / min & 155,24 & 8,49 & 149,08 & 20,17 \\
\hline ŠSD (VeS1) \% nuo maks., tv. / min & 78,39 & 2,63 & 76,82 & 7,31 \\
\hline $\mathrm{O}_{2} \mathrm{VeS} 1,1 / \mathrm{min}$ & 3,21 & 0,34 & 2,62 & 0,60 \\
\hline $\mathrm{O}_{2} \mathrm{VeS}, \% \mathrm{VO}_{2 \max }$ & 63,50 & 7,71 & 62,53 & 12,11 \\
\hline Veiksmingumas ties VeS1, $\mathrm{ml} / \mathrm{W}$ & 9,87 & 0,71 & 9,75 & 1,19 \\
\hline 2 ventiliacinis slenkstis, $W$ & 340,43 & 53,95 & 280,13 & 58,48 \\
\hline 2 ventiliacinis slenkstis, $\mathrm{W} / \mathrm{kg}$ & 4,51 & 0,58 & 4,43 & 0,89 \\
\hline Ventiliacija (VeS2), 1 / min & 98,05 & 21,80 & 93,79 & 23,70 \\
\hline ŠSD (VeS2), tv. / min & 178,38 & 9,22 & 179,00 & 8,99 \\
\hline ŠSD (VeS2) \% nuo maks., tv. / min & 90,25 & 3,37 & 92,57 & 3,35 \\
\hline $\mathrm{O}_{2} \mathrm{VeS} 2,1 / \mathrm{min}$ & 4,11 & 0,62 & 3,62 & 0,61 \\
\hline $\mathrm{O}_{2} \mathrm{VeS} 2, \% \mathrm{VO}_{2 \max }$ & 81,09 & 11,39 & 86,70 & 8,77 \\
\hline Veiksmingumas ties VeS2, $\mathrm{ml} / \mathrm{W}$ & 9,01 & 2,40 & 8,49 & 2,93 \\
\hline $\mathrm{VO}_{2 \max }, 1 / \min$ & 5,07 & 0,40 & 4,18 & 0,55 \\
\hline $\mathrm{VO}_{2 \max }, \mathrm{ml} / \mathrm{kg} / \mathrm{min}$ & 67,45 & 6,44 & 66,42 & 8,15 \\
\hline $\mathrm{SSSD}_{\max }$, tv. / min & 197,57 & 6,41 & 193,56 & 11,57 \\
\hline $\mathrm{VE}_{\max }, 1 / \min$ & 171,17 & 13,79 & 145,56 & 39,94 \\
\hline $\mathrm{KD}_{\max }, \mathrm{k} . / \min$ & 52,76 & 8,55 & 55,96 & 10,55 \\
\hline Didžiausia galia, W & 448,21 & 25,83 & 349,13 & 60,76 \\
\hline Didžiausia galia, W / kg & 5,97 & 0,43 & 5,50 & 0,60 \\
\hline $\mathrm{O}_{2}$ - pulsas maksimalus & 26,61 & 2,33 & 22,14 & 2,58 \\
\hline $\mathrm{O}_{2}$ - pulsas maksimalus $/ \mathrm{m}^{2}$ & 12,99 & 2,19 & 12,52 & 1,44 \\
\hline Maks. kvėpavimo koeficientas & 1,25 & 0,12 & 1,22 & 0,09 \\
\hline Laktatas po $5 \mathrm{~min}, \mathrm{mmol} / 1$ & 11,47 & 3,31 & 11,74 & 4,73 \\
\hline Laktatas po $20 \mathrm{~min}, \mathrm{mmol} / \mathrm{l}$ & 5,56 & 2,54 & 4,35 & 2,69 \\
\hline Laktatas po $20 \mathrm{~min}, \%$ & 49,92 & 19,47 & 39,64 & 22,63 \\
\hline
\end{tabular}

Lentelè. Nenutrūkstamo nuosekliai didinamo veloergometrinio krūvio rodikliai 
1 pav. Skirtingo amžiaus ir meistriškumo dviratininkų absoliutūs aerobinio pajègumo rodikliai

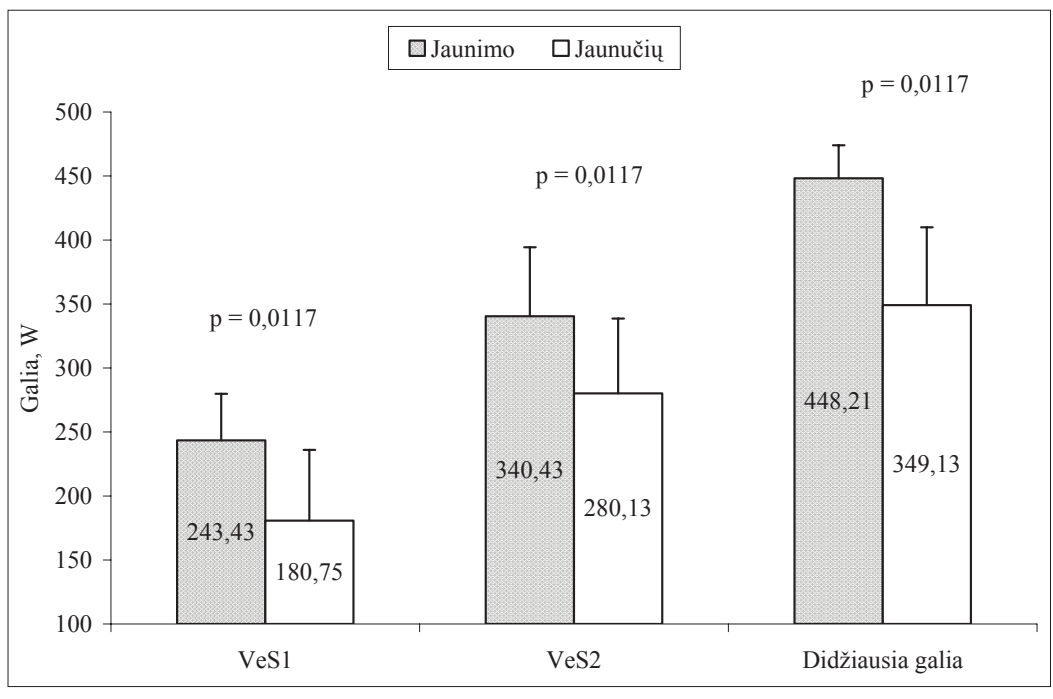

2 pav. Skirtingo amžiaus ir meistriškumo dviratininkų santykiniai aerobinio pajègumo rodikliai

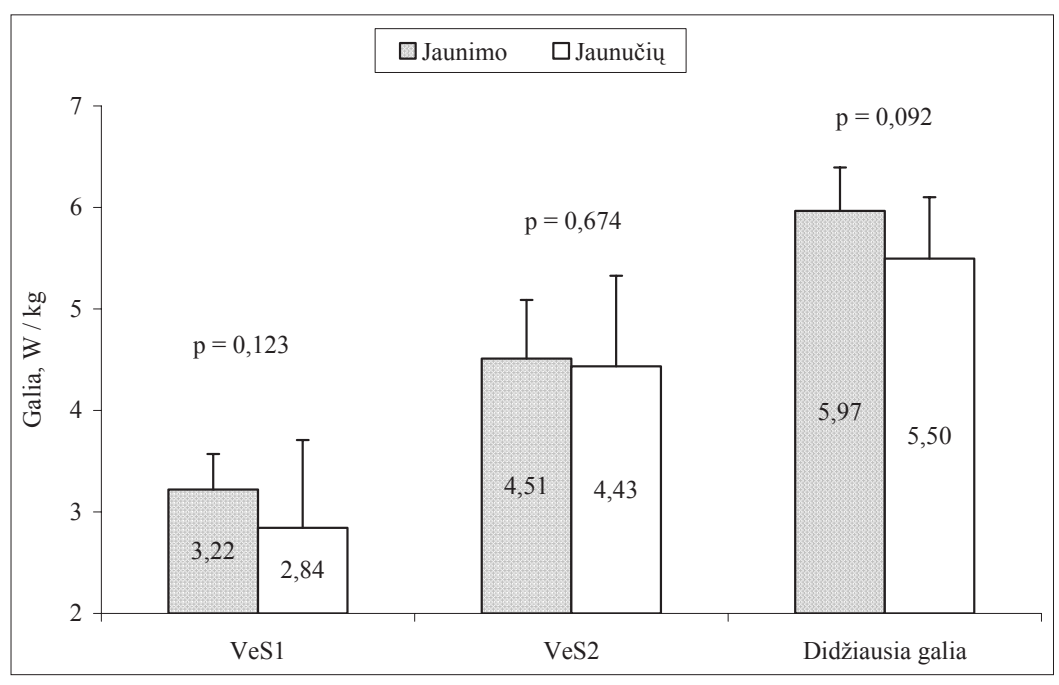

3 pav. Skirtingo amžiaus ir meistriškumo dviratininkų ŠSD rodikliai nuosekliai didinamo veloergometrinio krūvio metu

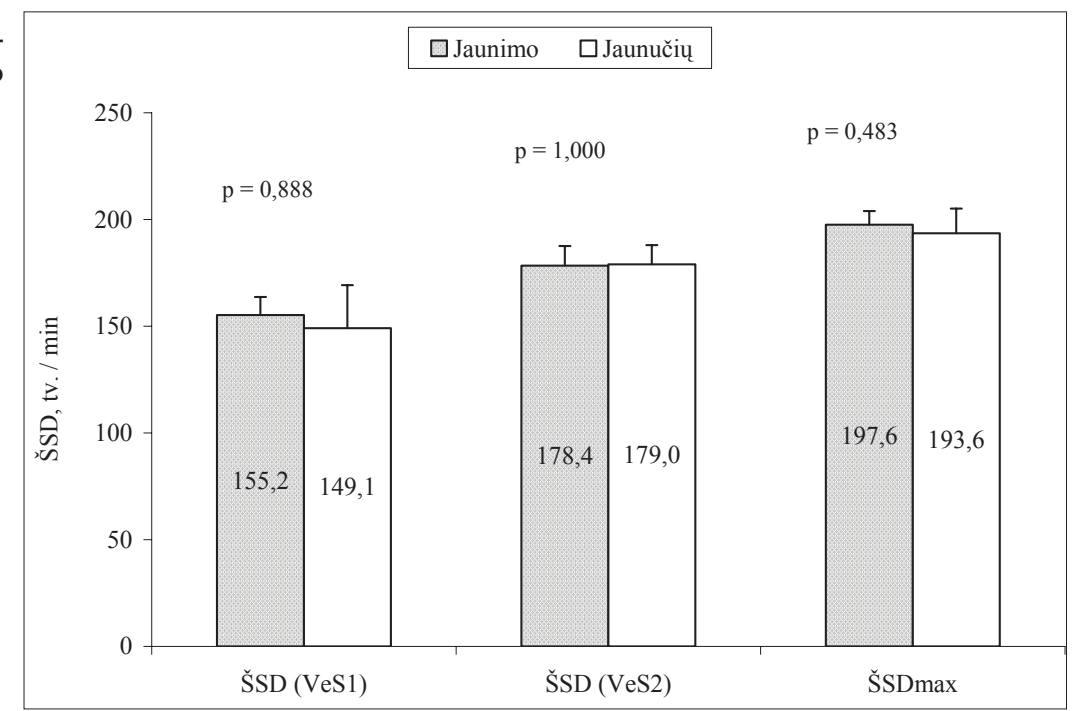

Plaučių ventiliacijos maksimalios ir submaksimalios reikšmès buvo didesnès jaunimo grupejje, nors statistiškai reikšmingai skyrèsi tik plaučiu ventiliacijos rodikliai ties VeS1 (4 pav.). Absoliučios maksimaliojo deguonies suvartojimo reikšmès buvo reikšmingai didesnès jaunimo grupeje, o santykinès nesiskyrè (5 ir 6 pav.). Darbo veloergome- tru mechaninis veiksmingumas buvo panašus tirtose grupése ( 7 pav.), kraujo laktato koncentracija po krūvio taip pat nesiskyrè (8 pav.). Deguonies suvartojimas ties VeS1 ir VeS2, išreikštas procentais nuo $\mathrm{VO}_{2 \max }$, statistiškai reikmingai nesiskyrè, nors šis rodiklis ties VeS2 buvo didesnis jaunučiu grupejje ( 9 pav.). 


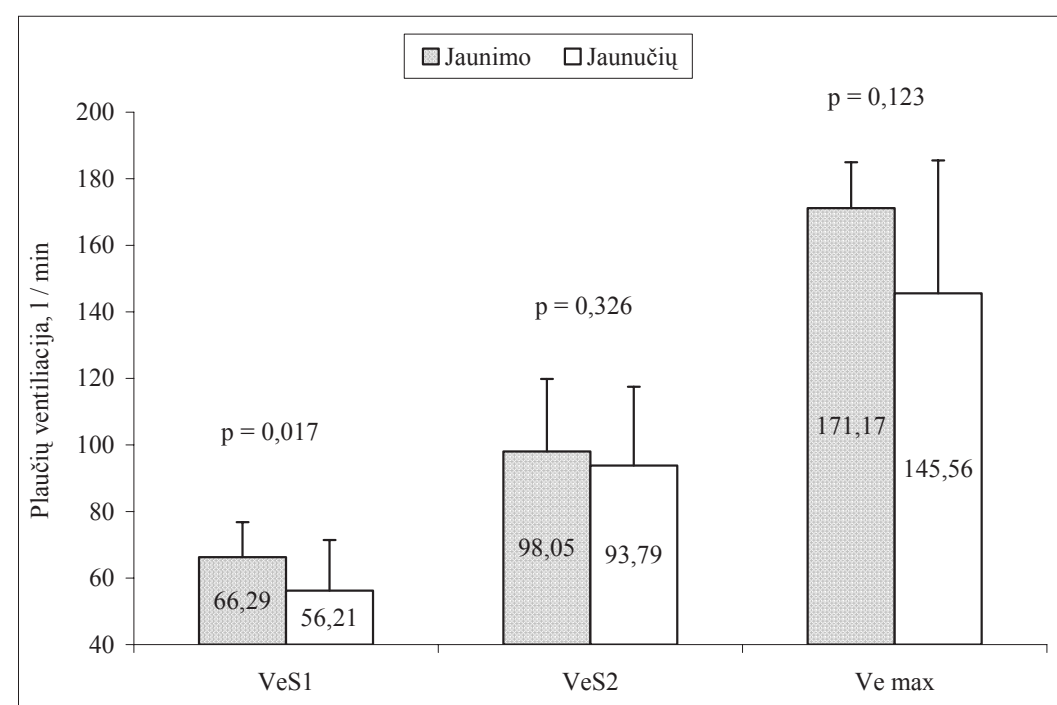

4 pav. Skirtingo amžiaus ir meistriškumo dviratininkų plaučių ventiliacijos rodikliai nuosekliai didinamo veloergometrinio krūvio metu
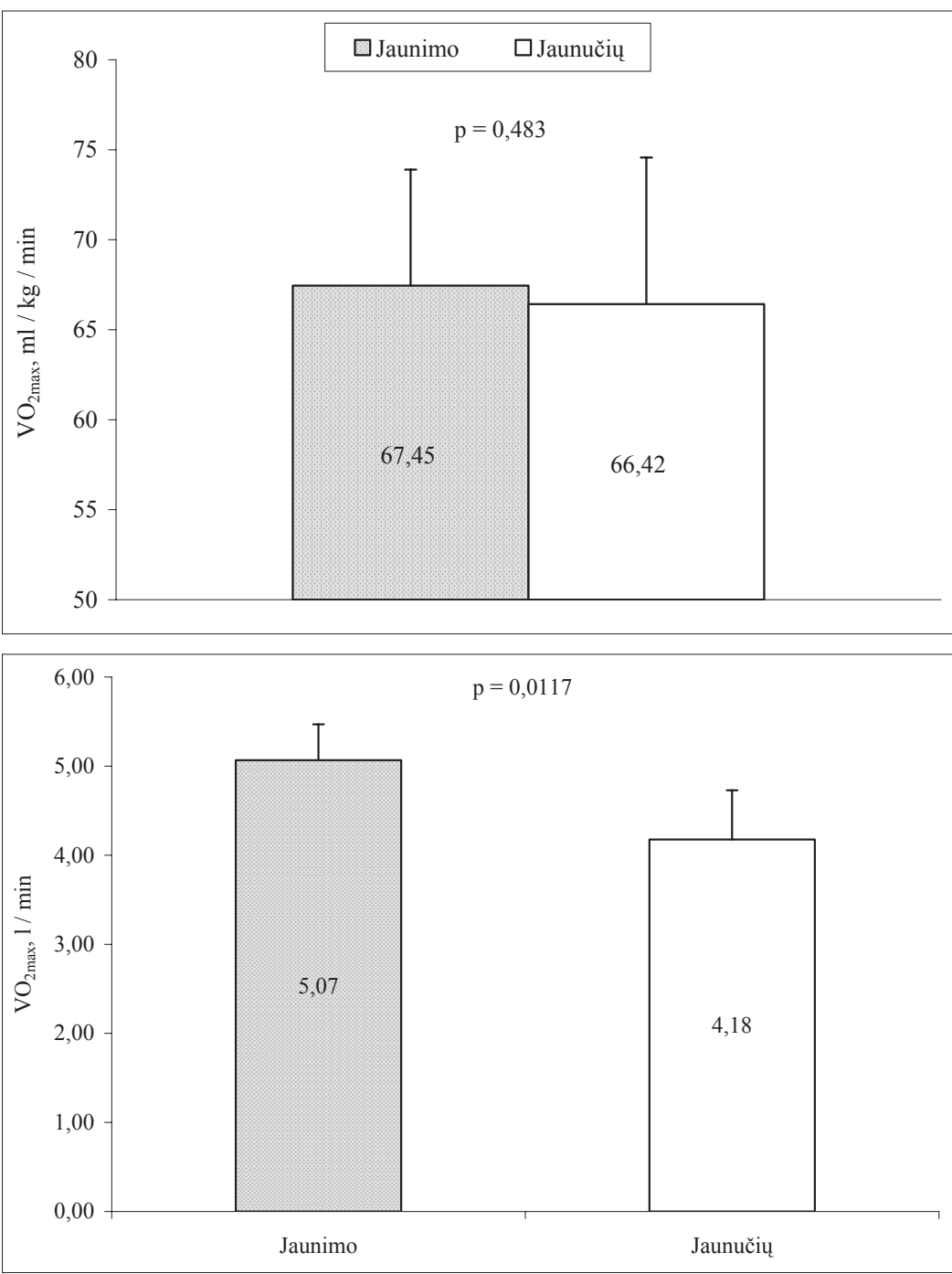

6 pav. Skirtingo amžiaus ir meistriškumo dviratininkų absoliutus $\mathrm{VO}_{2 \max }$

\section{REZULTATŲ APTARIMAS}

Šiuo tyrimu nustatėme jaunučių ir jaunimo grupès Lietuvos jaunujų dviratininkų fiziologinius skirtumus, kurie pasireiškia atliekant NDK veloergometru laboratorinemis sąlygomis. Svar-
5 pav. Skirtingo amžiaus ir meistriškumo dviratininkų santykinis $\mathrm{VO}_{2 \max }$ 
7 pav. Skirtingo amžiaus ir meistriškumo dviratininkų darbo veiksmingumo rodikliai

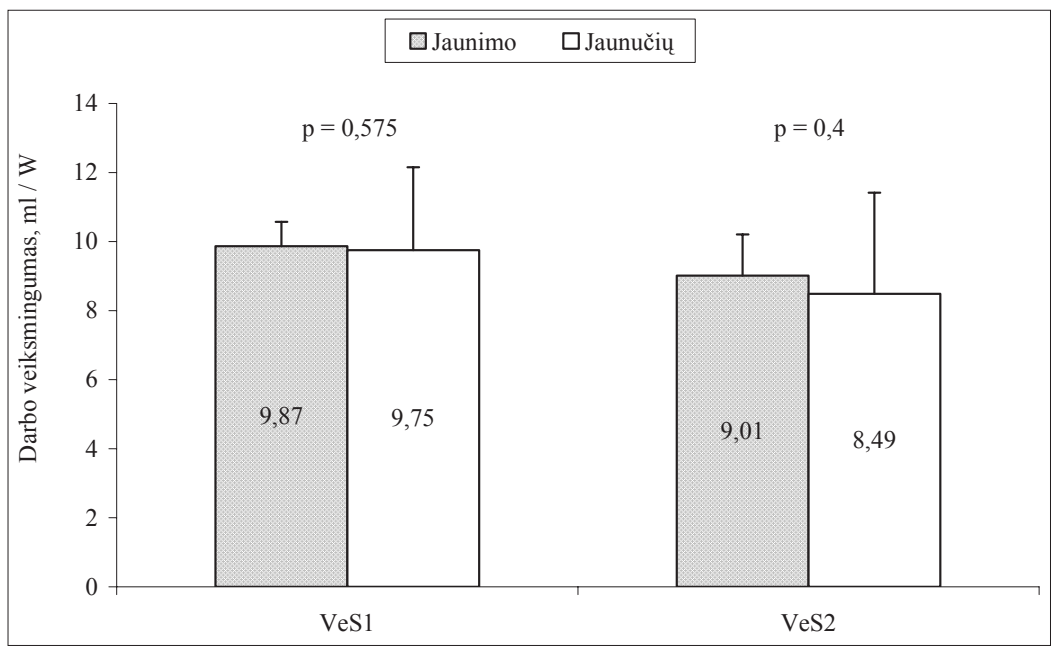

8 pav. Skirtingo amžiaus ir meistriškumo dviratininkų kraujo laktato koncentracija po nuosekliai didinamo veloergometrinio krūvio
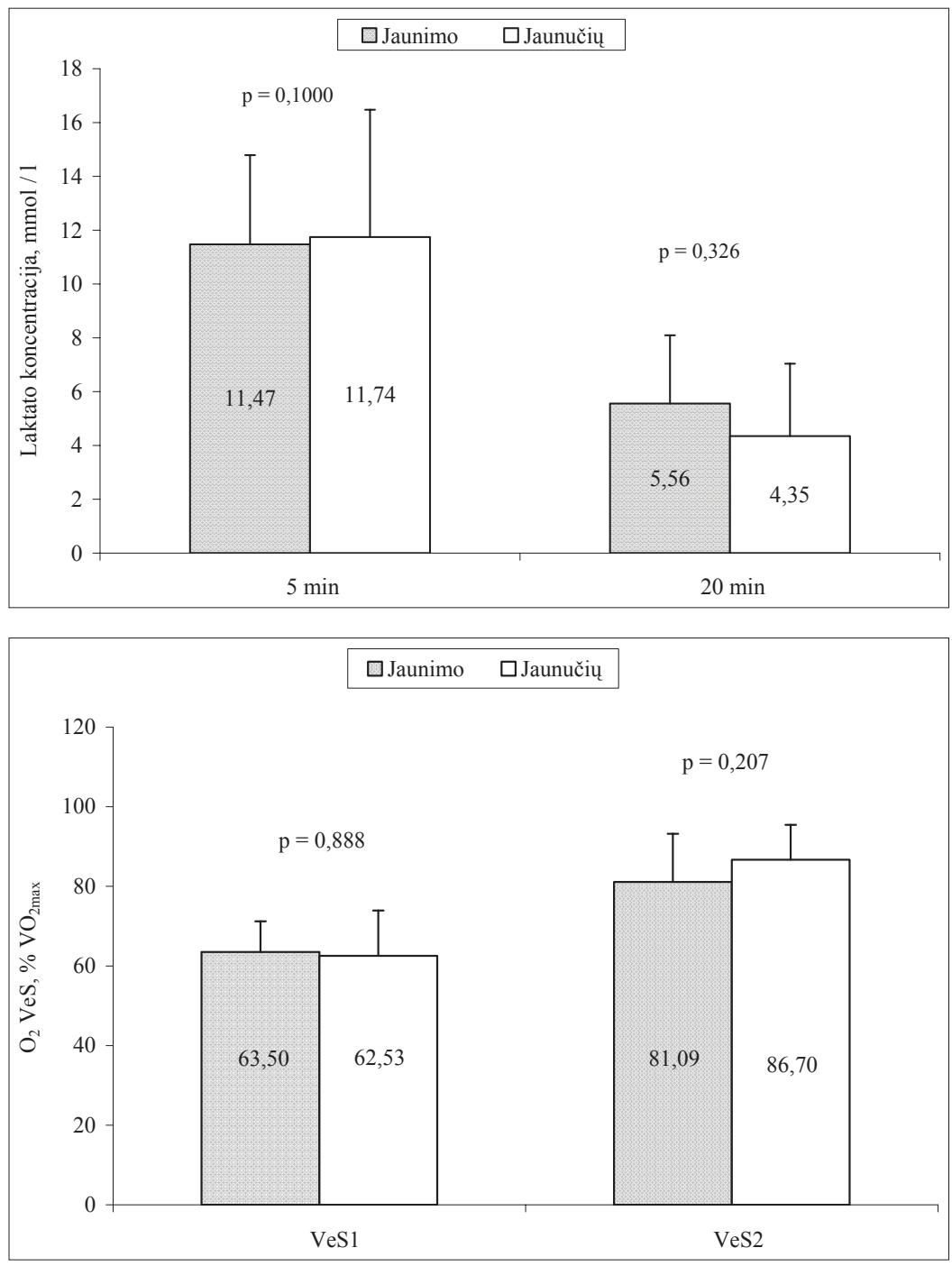

9 pav. Skirtingo amžiaus ir meistriškumo dviratininkų santykinis maksimalusis deguonies suvartojimas ties pirmu ir antru ventiliaciniu slenksčiu

(Lucia et al., 1998) palygino geriausių mėgejjų

ventiliaciniai slenksčiai, testo metu jie pasiekè didesnę absoliučią galią ir jų plaučių ventiliacija buvo didesnè. Palyginus minètuosius rodiklius kūno masės atžvilgiu, skirtumas tarp grupių nebebuvo statistiškai reikšmingas.

Literatūroje neaptikome tyrimų, kurių metu būtų palyginami skirtingo amžiaus jaunuju dviratininkų fiziologiniai rodikliai. A. Lucia ir kt. ir elito dviratininkų fiziologinius rodiklius atliekant NDK testa. Jie taip pat nepastebejo aerobinio pajėgumo rodiklių skirtumo tarp grupių, tačiau geriausių elito dviratininkų ventiliacinio slenksčio rodikliai buvo didesni, išreiškus ju dydi procentais nuo $\mathrm{VO}_{2 \max }$. Mūsų tyrimo minèti rodikliai skirtingo amžiaus ir meistriškumo 
jaunujų dviratininku grupèse nesiskyrè, nors jaunesniuju grupeje šis rodiklis buvo pastebimas didesnis ties antru ventiliaciniu slenksčiu. Lyginant minėtame straipsnyje pateiktus ir mūsu gautus aerobinio pajègumo rodiklius matyti, kad abiejų amžiaus grupių Lietuvos jaunieji dviratininkai atsilieka santykiniais $\mathrm{VO}_{2 \max }$, o jaunučiu grupès dviratininkai - ir absoliučiais $\mathrm{VO}_{2 \max }$ rodikliais. Mūsų dviratininkų rodikliai mažesni už daugelyje tyrimų nustatytas geriausių dviratininkų santykines $\mathrm{VO}_{2 \max }$ reikšmes, kurios siekia 70-80 ml / kg / min (Burke, 1980; Mujika, Padilla, 2001; Saltin, Astrand, 1967). Minètu A. Lucia ir kt. (1998) tyrimu nustatytos kur kas didesnès plaučiu ventiliacijos ties antru ventiliaciniu slenksčiu ir didžiausios plaučių ventiliacijos NDK metu reikšmès negu mūsų tirtu dviratininkų. Tiesa, mūsų vyresnių dviratininkų minèto rodiklio reikšmės buvo panašios kaip geriausiu A. Lucia tirtu mėgèjų. Taigi ryškejja svarbiausi NDK metu pastebimi ir su meistriškumu susiję rodikliai: aukšti absoliutūs ir santykiniai
$\mathrm{VO}_{2 \max }$, labai dideli plaučių ventiliacijos rodikliai, ypač dirbant ties antru ventiliaciniu slenksčiu ir maksimaliu aerobiniu intensyvumu, didesnès santykinès deguonies suvartojimo reikšmès pasiekus ventiliacinius slenksčius. Mūsų tyrimo metu pastebètas absoliutaus $\mathrm{VO}_{2 \max }$ skirtumas jaunu dviratininkų amžiaus grupèse yra daugiau kiekybinio pobūdžio, t. y. jị lėmè didesnè absoliuti vyresnių dviratininku kūno masè, bet kokybinis raumenų gebejjimas vartoti deguonị krūvio metu, matyt, nesiskiria.

\section{IŠVADA}

Atliekant nuosekliai didinamą fizinị krūvị veloergometru, vyresnių ir didesnio meistriškumo jaunujų dviratininkų absoliutūs aerobinès galios rodikliai (absoliučios $\mathrm{VO}_{2 \max }$ ir absoliučios ventiliaciniu slenksčiu reikšmès) yra geresni. Santykiniai aerobinio pajègumo rodikliai (padalyti iš kūno masès) yra panašūs jaunučiu ir jaunimo dviratininku grupèse.

\section{LITERATŪRA}

Burke, E. R. (1980). Physiological characteristics of competitive cyclists. Physician Sports Medicine, 8, 79-84.

Lucia, A., Hoyos, J., Chicharro, J. L. (2001 a). Physiology of professional road cycling. Sports Medicine, 31, $325-337$

Lucia, A., Hoyos, J., Chicharro, J. L. (2001 b). Preferred pedalling cadence in professional cycling. Medicine and Science in Sports and Exercise, 33, 1361-1366.

Lucia, A., Hoyos, J., Pe'Rez, M., Chicharro, J. L. (2000). Heart rate and performance parameters in elite cyclists: A longitudinal study. Medicine and Science in Sports and Exercise, 32, 1777-1782.

Lucía, A., Pardo, J., Durántez, A., Hoyos, J., Chicharro, J. L. (1998). Physiological differences between professional and elite road cyclists. International Journal of Sports Medicine, 19 (5), 342-348.

Mujika, I., Padilla, S. (2001). Physiological and performance characteristics of male professional road cyclists. Sports Medicine, 31, 479-487.

Saltin, B., Astrand, P. O. (1967). Maximal oxygen uptake in athletes. Journal of Applied Physiology, 23, 353-358.

Swain, D. P., Coast, J. R., Clifford, P. S. et al. (1987). Influence of body size on oxygen consumption during bicycling. Journal of Applied Physiology, 62, 668-672.

Tsunawake, N., Tahara, Y., Yukawa, K., Senju, H. (1993). Body composition, $\mathrm{VO}_{2 \max }$ and $\mathrm{O}_{2}$ debt max in elite senior high school male cyclists. The Annals of Physiological Anthropology, 12 (6), 351-362. 


\title{
AEROBIC CAPACITY OF LITHUANIAN YOUNG CYCLISTS OF DIFFERENT AGE AND PERFORMANCE LEVEL
}

\author{
Gintautas Volungevičius, Arvydas Stasiulis, Pranas Mockus \\ Lithuanian Academy of Physical Education, Kaunas, Lithuania
}

\begin{abstract}
The aim of the study was to compare aerobic capacity of young Lithuanian cyclists of different age and performance level by means of increasing cycling exercise with cadence of $90 \mathrm{rpm}$. (Lucia et al., 2001). Eight $15-16$ year old (training experience $-2-3$ years) and eight $19-23$ year old (training experience $-5-8$ years) cyclists participated in the study. They performed increasing ramp cycling exercise until voluntary eqaustion on the cycle ergometer "Ergoline". Gas exchange parameters and the heart rate were continuously recorded using a portable analyser „Oxycon Mobile“ (Jaeger, Germany), aerobic capacity parameters were determined later. Absolute values of maximum oxygen uptake $\left(\mathrm{VO}_{2 \max }\right)$, ventilatory thresholds, peak test power, pulmonary ventilation were significantly higher in the older group. However, relative $\mathrm{VO}_{2} \max$ and ventilatory threshold values (expressed per kg of body mass) as well as work efficiency and HR values were not significantly different between the groups investigated. The results showed that the only advantage of the older group and their better performance during increasing cycling was associated with the parameters of higher absolute aerobic capacity.
\end{abstract}

Keywords: maximum oxygen uptake, ventilatory threshold, aerobic capacity, age of young cyclists.

Gauta 208 m. liepos 7 d.

Received on July 7, 2008

Priimta 2008 m. rugsèjo $9 \mathrm{~d}$.

Accepted on September 9, 2008

\author{
Gintautas Volungevičius \\ Lietuvos kūno kultūros akademija \\ (Lithuanian Academy of Physical Education) \\ Sporto g. 6, LT-44221 Kaunas \\ Lietuva (Lithuania) \\ Tel +37037302671 \\ E-mail g.volungevicius@1kka.1t
}

